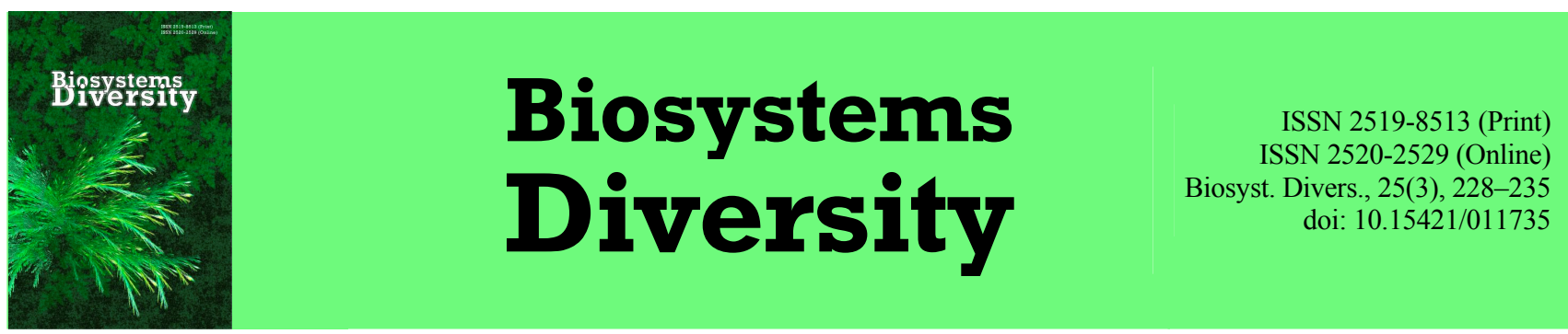

\title{
Analysis of differences of growth and phenology of provenances of Scots pine (Pinus sylvestris) in provenance experiment at Žepče
}

\author{
D. Ballian*,**, S. Šito* \\ University of Sarajevo, Sarajevo, Bosnia and Herzegovina \\ Slovenian Forestry Institute, Ljubljana, Slovenia
}

Article info

Received 14.06.2017

Received in revised form 17.07 .2017

Accepted 18.07.2017

University of Sarajevo,

Zagrebacka, 20, Sarajevo, 71000,

Bosnia and Herzegovina.

Slovenian Forestry Institute, Večna pot, 2,

Ljubljana, 1000, Slovenia.

E-mail:

balliandalibor9@gmail.com,

sanela4500@hotmail.com
Ballian, D., \& Šito, S. (2017). Analysis of differences of growth and phenology of provenances of Scots pine (Pinus sylvestris) in provenance experiment at Žepče. Biosystems Diversity, 25(3), 228-235. doi:10.15421/011735

This paper analyses the growth and phenology of fourteen European provenances of Scots pine at the international experimental plot at Zepce. The experiment with the provenances was developed during the spring of 2012 with two $(2+0)$ year old plants. In total 1400 Scots pine saplings were planted in an experimental random block layout, fourteen provenances in four repetitions ( 4 x 25 plants). The experiment is composed of provenances from ten European countries: Austria (Traisen, Rein, Sistrans), Bosnia and Herzegovina (Bugojno), Scotland (Shieldaig), Ukraine (IvanoFrankivsk), Slovakia (Hanusovce), Romania (Sacueini), Norway (Narvik), Germany (Trippstadt), Poland (Raciane Nida) and Italy (Ca del Lupo, Fenestrelle, Piani - Valda). The morphological results relate to the differences in survival, height, diameter on the root neck and the ratio of these measurements to the height of the saplings of different provenances of Scots pine. Phenological details relate to the phenology of the buds and complete formation of pine needles. All of the details researched have yielded notably different findings. The results of the research can play a significant role in reforestation as well as the preservation of the genetic wealth of Scots pine.

Keywords: circumference at the neck of the root; height; phenology

\section{Introduction}

In the highly complex ecological, economic and social conditions in this country as in the world as a whole, forests, one of the most complex natural ecosystems, constitute an important natural resource, not only for economic reasons but also because of their ever increasing environmental importance. On account of their environmental and social value, forests thus occupy a singular position at the global environmental level, and are of particular interest for our country.

Scots pine (Pinus sylvestris L.) is among the more important tree species in our forests, and is characterized by great genetic variability and complex population structure. The species inhabits large areas of bare, rocky ground and degraded habitats. As a pioneer species, it is tolerant of poor soil, drought, wind and frost (Houston Durant et al., 2016). According to the preliminary results of the second forest inventory in Bosnia and Herzegovina, pure stands of productive Scots pine occupy 38,000 ha (Lojo and Balić, 2011). The importance of this species for our country is demonstrated by the fact that in excess of five million Scots pine seedlings are raised here each year (Ballian, 2000). In this country, differences within Scots pine populations can be expected at the morphological level (Stefanović, 1980), and in the productive potential of the provenances studied (Mikić, 1991), as confirmed by Ballian et al. (2009). Further research, combining the results of the test analyses with exact details of the ecological parameters of the parent stands from which the studied provenances originated, is necessary in order to reach a final conclusion on their ecotypes genetic variability.

Scots pine populations in the Mediterranean region and central Europe are relict communities from the Pleistocene (Mirov, 1967). Small areas of ancient Scots pine forest can still be found in the Balkans. As a result of unchecked exploitation and the lack of organized biological regeneration, there is an urgent need for a conservation plan for the species in Bosnia and Herzegovina. This country now forms the southern limit of the distribution of Scots pine, as a result of the climate changes brought about by global warming. The first international trial of Scots pine progeny took place in 1907, under the auspices of the International Union of Forest Research Organizations (IUFRO). The trial consisted of a provenance test of 13 populations from various European countries. In the initial stage the results revealed significant differences between provenances (Giertych and Oleksyn, 1992). The trial was prompted by the fact that by the end of the 19th century Scots pine seed had been introduced to Germany from Belgium, France, Austria, Hungary and Russia (Ludemann, 1961). Another three similar trials were conducted (1910-1916, 1938-1939, and 1982) with a larger number of provenances. The conclusion (Oleksyn, 1988) was that seeds originating from populations south of the Baltic Sea, Southern Belarus and western Ukraine were best used for the introduction of Scots pine. These provenances are ideal for central and Eastern Europe, whereas those of Scandinavia, the Alps and the Mediterranean do not display a high degree of adaptability. Research to date into the variability of Scots pine has shown that the species has great variability at the ecotype level, though certain ecotypes could not be clearly defined and distinguished from others. Further research is required in such cases (Vidaković and Franjić, 2004).

In their study of isoenzyme markers, Prus-Glowacki et al. (1993) obtained limited genetic distances between European Scots pine populations. They state that there is some degree of correspondence with geographical distribution. Prus-Glowacki and Stephan (1994) reported a clear distinction between the Spanish population on the one hand and the Nordic and Central European populations on the other. Puglisisi and Attolico (2000) studied the genetic differences between seven alpine populations and one Apennine. Nilsson and Walfridsson (1995) conducted a detailed study of phenology, dry matter and frost tolerance in 18 clones originating from three regions of northern Sweden, while clones from the southern and 
central regions are more sensitive than those from the north. Latitude has a significant impact on frost tolerance during the growth period, but not in winter and spring. Alia et al. (2001) studied the growth and survival rates of Spanish provenances. In general, German populations outgrew Spanish populations. This was found to be due to climatic and geographical variability. Perks and Ennos (1999) recorded significant variability in growth characteristics and phenology between populations in a combined study of provenances and progeny in Scotland. Persson and Beuker (1997) used data on the growth of 18 populations in provenance studies in Sweden, and found a high correlation between temperature and population growth. Persson and Andersson (2003) concluded from their study that there is a strong genetic link at the family level between growth and survival rates.

The aim of this study was to determine variability in the juvenile phase by studying the intra provenance and inter provenance variability of 14 European Scots pine provenances. This should reveal whether the adaptability of Scots pine reflects its genetic structure.

\section{Materials and methods}

In the autumn of 2012 the Žepče Forestry Office set up a trial with fourteen Scots pine provenances (Table 1). The trial was conducted at a site in Žepče Municipality, Zenica-Doboj Canton. The Žepče Forestry Office, which manages the Krivajsko forestry management area, laid out an experimental site in sections 42 and 43 of the Nemila Pepelari management unit, at an altitude of $600 \mathrm{~m}$, with a south-west exposure.
Table 1

Details of the Scots pine provenances studied

\begin{tabular}{|c|c|c|c|c|c|}
\hline $\begin{array}{l}\text { Mark of } \\
\text { provenance } \\
\text { in plot }\end{array}$ & $\begin{array}{l}\text { Country } \\
\text { of origin }\end{array}$ & $\begin{array}{l}\text { Code for } \\
\text { the pro- } \\
\text { venance }\end{array}$ & Provenance name & $\begin{array}{l}\text { North } \\
\text { latitude }\end{array}$ & $\begin{array}{c}\text { East } \\
\text { ongitude }\end{array}$ \\
\hline 1 & Austria & $\mathrm{A} 1$ & Kobersdorf/Lackenbach & $47^{\circ} 35^{\prime}$ & $16^{\circ} 26^{\prime}$ \\
\hline 2 & Austria & A2 & $\begin{array}{l}\text { Urbarialgemeinde Dörfl, } \\
\text { Pannholz, Burgenland }\end{array}$ & $47^{\circ} 29^{\prime}$ & $16^{\circ} 27^{\prime}$ \\
\hline 3 & Austria & A3 & $\begin{array}{l}\text { Hochwolkersdorf } \\
\text { Stift Reichersberg }\end{array}$ & $47^{\circ} 41^{\prime}$ & $16^{\circ} 11^{\prime}$ \\
\hline 4 & Bosnia & B1 & Bugojno & $44^{\circ} 03^{\prime}$ & $17^{\circ} 27^{\prime}$ \\
\hline 5 & Scotland & S1 & Shieldaig & $57^{\circ} 36^{\prime}$ & $05^{\circ} 55^{\prime}$ \\
\hline 6 & Ukraine & U1 & IvanoFrankivsk & $48^{\circ} 56^{\prime}$ & $24^{\circ} 31^{\prime}$ \\
\hline 7 & Slovakia & SL1 & Hanušovce & $49^{\circ} 01^{\prime}$ & $21^{\circ} 30^{\prime}$ \\
\hline 8 & Romania & $\mathrm{R} 1$ & Sacueni & $47^{\circ} 21^{\prime}$ & $22^{\circ} 05^{\prime}$ \\
\hline 9 & Norway & $\mathrm{N} 2$ & Narvik & $68^{\circ} 25^{\prime}$ & $17^{\circ} 33^{\prime}$ \\
\hline 10 & Germany & $\mathrm{NJ} 2$ & Trippstadt & $49^{\circ} 21^{\prime}$ & $07^{\circ} 46^{\prime}$ \\
\hline 11 & Poland & P1 & Raciane - Nida & $53^{\circ} 37^{\prime}$ & $21^{\circ} 29^{\prime}$ \\
\hline 12 & Italy & I1 & Ca Del Lupo & $43^{\circ} 18^{\prime}$ & $13^{\circ} 27^{\prime}$ \\
\hline 13 & Italy & I2 & Fenestrelle (To) & $45^{\circ} 01^{\prime}$ & $07^{\circ} 03^{\prime}$ \\
\hline 14 & Italy & I3 & Piani - Valda (Tn) & $46^{\circ} 13^{\prime}$ & $11^{\circ} 16^{\prime}$ \\
\hline
\end{tabular}

Here an area of 0.6 ha was marked out, on which all existing sessile oaks and hornbeam were felled, and the site was cleared and prepared for planting the seedlings. Two-year-old seedlings were planted in the spring of 2012 in the traditional way, in a $30 \mathrm{~cm}$ deep hole, with the seedlings set $2 \times 2 \mathrm{~m}$ apart. Within the blocks, the seedlings were planted in a random layout (Fig. 1).

\begin{tabular}{|c|c|c|c|c|}
\hline $\begin{array}{c}14 \\
\text { Italy I3 }\end{array}$ & $\begin{array}{c}7 \\
\text { Slovakia } \\
\end{array}$ & $\begin{array}{c}13 \\
\text { Italy } \mathbf{I 2}\end{array}$ & - & - \\
\hline $\begin{array}{c}9 \\
\text { Norway }\end{array}$ & $\begin{array}{c}10 \\
\text { Germany }\end{array}$ & $\begin{array}{c}11 \\
\text { Poland }\end{array}$ & $\begin{array}{c}12 \\
\text { Italy II }\end{array}$ & - \\
\hline $\begin{array}{c}4 \\
\text { Bosnia }\end{array}$ & $\begin{array}{c}5 \\
\text { Scotland }\end{array}$ & $\begin{array}{c}6 \\
\text { Ukraine }\end{array}$ & - & $\begin{array}{c}8 \\
\text { Romania }\end{array}$ \\
\hline $\begin{array}{c}13 \\
\text { Italy } \mathbf{L} 2\end{array}$ & $\begin{array}{c}14 \\
\text { Italy I3 }\end{array}$ & $\begin{array}{c}1 \\
\text { Austria Al }\end{array}$ & $\begin{array}{c}2 \\
\text { Austria A2 }\end{array}$ & $\begin{array}{c}3 \\
\text { Austria A3 } 3\end{array}$ \\
\hline $\begin{array}{c}8 \\
\text { Romania }\end{array}$ & $\begin{array}{c}9 \\
\text { Norway }\end{array}$ & $\begin{array}{c}10 \\
\text { Germany }\end{array}$ & $\begin{array}{c}11 \\
\text { Poland }\end{array}$ & $\begin{array}{c}12 \\
\text { Italy I1 }\end{array}$ \\
\hline $\begin{array}{c}3 \\
\text { Austria A3 }\end{array}$ & $\begin{array}{c}4 \\
\text { Bosnia }\end{array}$ & $\begin{array}{c}5 \\
\text { Scotland }\end{array}$ & $\begin{array}{c}6 \\
\text { Ukraine }\end{array}$ & $\begin{array}{c}7 \\
\text { Slovakia }\end{array}$ \\
\hline $\begin{array}{c}12 \\
\text { Italy Il }\end{array}$ & $\begin{array}{c}13 \\
\text { Italy I2 }\end{array}$ & $\begin{array}{c}14 \\
\text { Italy I3 }\end{array}$ & $\begin{array}{c}1 \\
\text { Austria Al }\end{array}$ & $\begin{array}{c}2 \\
\text { Austria A2 }\end{array}$ \\
\hline $\begin{array}{c}7 \\
\text { Slovakia }\end{array}$ & $\begin{array}{c}8 \\
\text { Romania }\end{array}$ & $\begin{array}{c}9 \\
\text { Norway }\end{array}$ & $\begin{array}{c}10 \\
\text { Germany }\end{array}$ & $\begin{array}{c}11 \\
\text { Poland }\end{array}$ \\
\hline $\begin{array}{c}2 \\
\text { Austria A2 }\end{array}$ & $\begin{array}{c}3 \\
\text { Austria A3 }\end{array}$ & $\begin{array}{c}4 \\
\text { Bosnia }\end{array}$ & $\begin{array}{c}5 \\
\text { Scotland }\end{array}$ & $\begin{array}{c}6 \\
\text { Ukraine }\end{array}$ \\
\hline $\begin{array}{c}11 \\
\text { Poland }\end{array}$ & $\begin{array}{c}12 \\
\text { Italy Il }\end{array}$ & $\begin{array}{c}13 \\
\text { Italy I2 }\end{array}$ & $\begin{array}{c}14 \\
\text { Italy I3 }\end{array}$ & $\begin{array}{c}1 \\
\text { Austria Al }\end{array}$ \\
\hline $\begin{array}{c}6 \\
\text { Ukraine }\end{array}$ & $\begin{array}{c}7 \\
\text { Slovakia }\end{array}$ & $\begin{array}{c}8 \\
\text { Romania }\end{array}$ & $\begin{array}{c}9 \\
\text { Norway }\end{array}$ & $\begin{array}{c}10 \\
\text { Germany }\end{array}$ \\
\hline $\begin{array}{c}1 \\
\text { Austria Al }\end{array}$ & $\begin{array}{c}2 \\
\text { Austria A2 }\end{array}$ & $\begin{array}{c}3 \\
\text { Austria A3 }\end{array}$ & $\begin{array}{c}4 \\
\text { Bosnia }\end{array}$ & $\begin{array}{c}5 \\
\text { Scotland }\end{array}$ \\
\hline
\end{tabular}

Fig. 1. Layout of planting of Scots pine provenances

The experimental site was surrounded by a $2 \mathrm{~m}$ wide fire break. The site was cleared (weeds and brush removed, grass mown) twice year (in late May and early October) from 2012 to 2016. Each separate block was planted with 25 seedlings $(5 \times 5)$, giving a total number of seedlings per provenance of 100 ( 25 seedlings $\times 4$ blocks).

The phenology of the provenances being studied was monitored in six characteristic phenophases, from dormant bud (winter) to fully open bud, as follows:

A. Dormant bud (winter bud, dark brown in colour) (Fig. 2A).

B. First signs of bud burst (buds swell, yellowish-green in colour, needle tips not yet pierced through openings) (Fig. 2B).

C. Marked bud elongation (buds elongated, yellowish-green in colour) (Fig. 2C).

D. First signs of bud opening and further elongation (green needles clearly visible, length c. $10 \mathrm{~cm}$ ) (Fig. 2D).

E. Needles developed, bud fully elongated (buds open, length c.
$15 \mathrm{~cm}$ ) (Fig. 2E).

F. Needles fully developed (green needles clearly developed). (Fig. 2F).

The phenological observations were conducted visually on the same day for all seedlings. Subjective errors in determining the various phenophases are minimal, as all observations were conducted by a single observer. Climatic data originate from the weather station (PDF Data Logger LOG32TH) set up at the site. Air temperature, air humidity and dew point for the period 15 March to 4 July 2016 are given in Fig. 3.

The average air temperature during the period was $21.4^{\circ} \mathrm{C}$, average air humidity was $54 \% \mathrm{rH}$, and average dew point was $7.1{ }^{\circ} \mathrm{C}$. The period to which these data relate includes the period during which phenological observations were conducted (30 March to $13 \mathrm{Ju}-$ ne), so that these data are relevant to the survey of the microclimatic conditions at the site. 


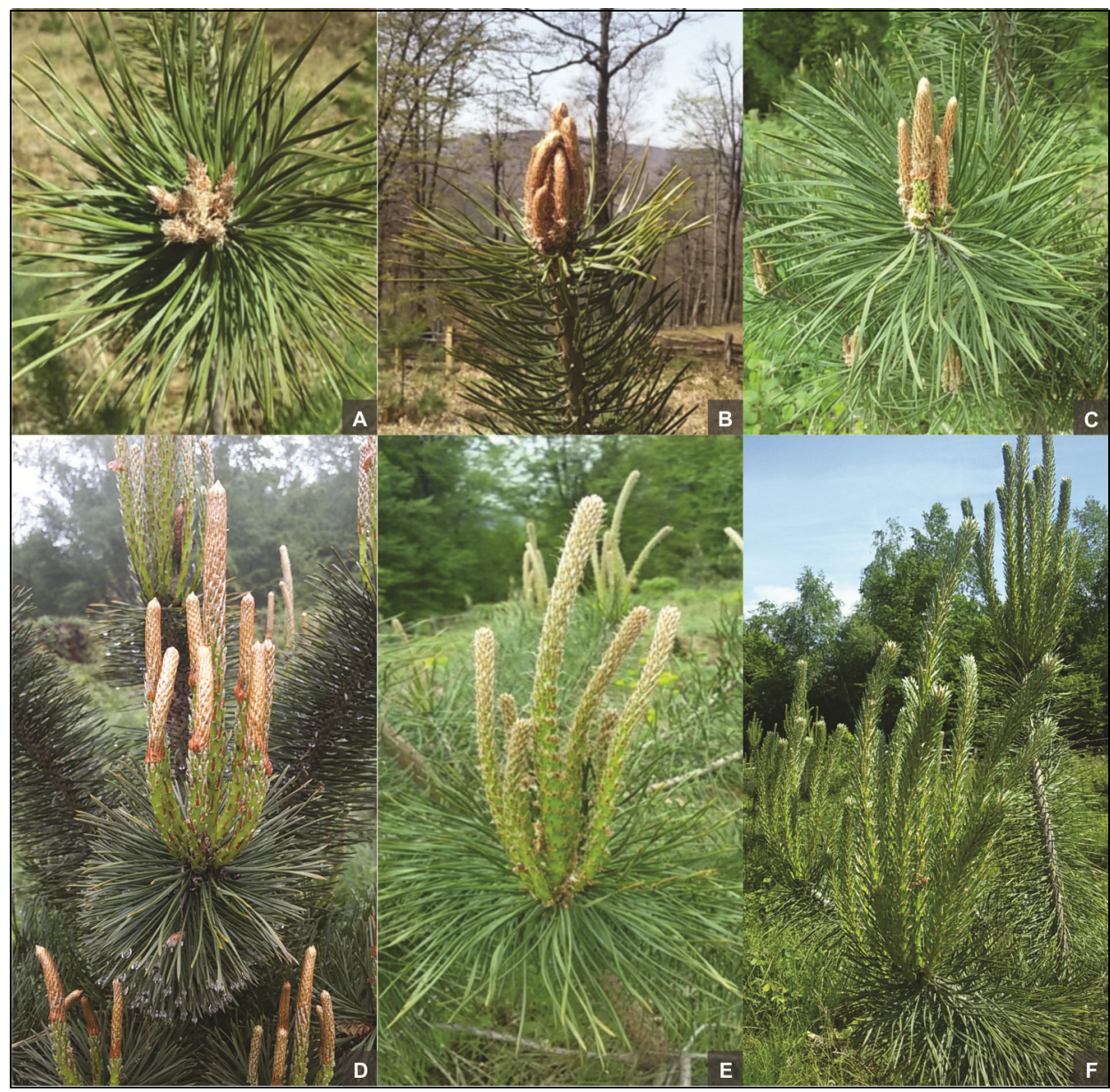

Fig. 2. Observed phenophases

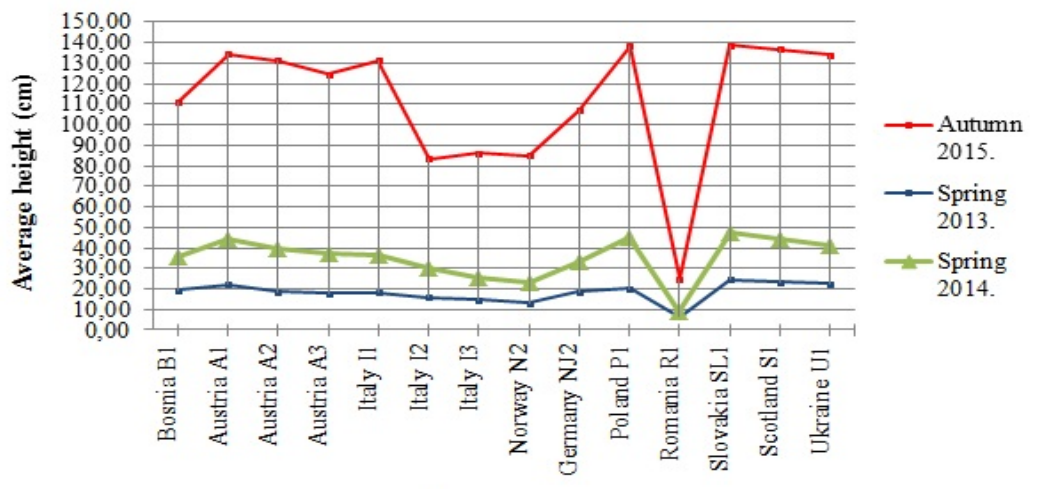

Provenance

Fig. 3. Overview of climatic characteristics at the trial site

The study was based on quantitative properties, on the basis of which classic provenance experiments are conducted, and on the examination of phenological phases in a given growth season. Statistics of the morphological features of Scots pine in the Žepče trial were collected with a view to studying the variability between provenances. The following measurements were taken:

- height and diameter of root collar in autumn 2014;

- monitoring phenological development from 30 March to 13 June 2016.

The statistics were processed using IBM SPSS Statistics 20 and Microsoft Excel 2010 software packages.

\section{Results}

Survival of seedlings by provenance. The results of the analysis of the plants' survival rate to 2015 are set out in Table 2. Com- parison with the findings from 2014 (Ban, 2015) will make this clearer. The success rate of the total of 1,400 seedlings planted was $60.5 \%$. From 2012, when the seedlings were planted to 2014, when the study was conducted, 847 plants survived.

The highest survival rate in 2014 was in the Poland P1 provenance, at $82 \%$, followed by Scotland S1 and Slovakia SL1, at $77 \%$. In 2015 the highest survival rate was found among the same provenances as in 2014, but at a lower level (Poland P1 - 80\%, Slovakia SL1 - 76\%), except for Scotland S1 provenance, which remained unchanged at $77 \%$. The lowest survival rate in 2014 was that of Romania $\mathrm{R} 1$ provenance, with $33 \%$ of the plants surviving, followed by Italy 12 provenance, at $32 \%$. In 2015 the survival rate of Romania R1 provenance remained unchanged at $33 \%$, while Italy I 2 provenance lost one more plant, giving a survival rate of $31 \%$. Overall, 2015 saw a further fall in survival rate to $58 \%$ overall, i.e. of 1400 seedlings planted, 812 had survived. 
Table 2

Survival rate of Scots pine seedlings of various provenances

\begin{tabular}{lccc}
\hline \multirow{2}{*}{ Provenance } & Number of planted & \multicolumn{2}{c}{ Number of surviving plants } \\
\cline { 3 - 4 } & seedlings & 2014 & 2015 \\
\hline Austria A1 & 100 & 55 & 54 \\
Austria A2 & 100 & 72 & 70 \\
Austria A3 & 100 & 66 & 64 \\
Bosnia B1 & 100 & 70 & 65 \\
Scotland S1 & 100 & 77 & 77 \\
Ukraine U1 & 100 & 56 & 54 \\
Slovakia SL1 & 100 & 77 & 76 \\
Romania R1 & 100 & 33 & 33 \\
Norway N2 & 100 & 67 & 58 \\
Germany Nj2 & 100 & 57 & 54 \\
Poland P1 & 100 & 82 & 80 \\
Italy I1 & 100 & 53 & 52 \\
Italy I2 & 100 & 32 & 31 \\
Italy I3 & 100 & 50 & 44 \\
Total & 1400 & 847 & 812 \\
\hline
\end{tabular}

The greatest change in the percentage of surviving plants from 2014 to 2015 was recorded in the provenances Norway N2 (from
$67 \%$ to $58 \%$ ), Italy I3 (from $50 \%$ to $44 \%$ ), Bosnia B1 (from $70 \%$ to $65 \%$ ), and Germany NJ2 (from $57 \%$ to $54 \%$ ). Scotland S1 and Romania R1 provenances remained unchanged from 2014 to 2015. During the same period the Austria A2, Austria A3, Ukraine U1 and Poland P1 provenances each lost two plants, while the Austria A1, Slovakia SL1 and Italy I1 and I2 each lost one.

Morphological study of Scots pine. Analysis of height. Descriptive statistics determined the number of seedlings for each provenance, the mean value of the height of the seedlings, the minimum and maximum values, and the standard deviation and coefficient of variation (Table 3). The greatest average height was that of Slovakia SL1 provenance, at $138.62 \mathrm{~cm}$, followed by Poland P1 at 138.28 (Fig. 4). The lowest average height was that of Romania R1 provenance $(24.85 \mathrm{~cm})$. The smallest seedling of the total of 812 , at $12 \mathrm{~cm}$, was from Romania R1 provenance, where the tallest was $50 \mathrm{~cm}$ - making this the only provenance that had no plants over $100 \mathrm{~cm}$ in height. The tallest plant was from Slovakia SL1 provenance, at $220 \mathrm{~cm}$. The only other to have a plant over $200 \mathrm{~cm}$ in height was Poland provenance, with one plant $217 \mathrm{~cm}$ in height. The mean height of all the plants as a whole was $117.85 \mathrm{~cm}$.

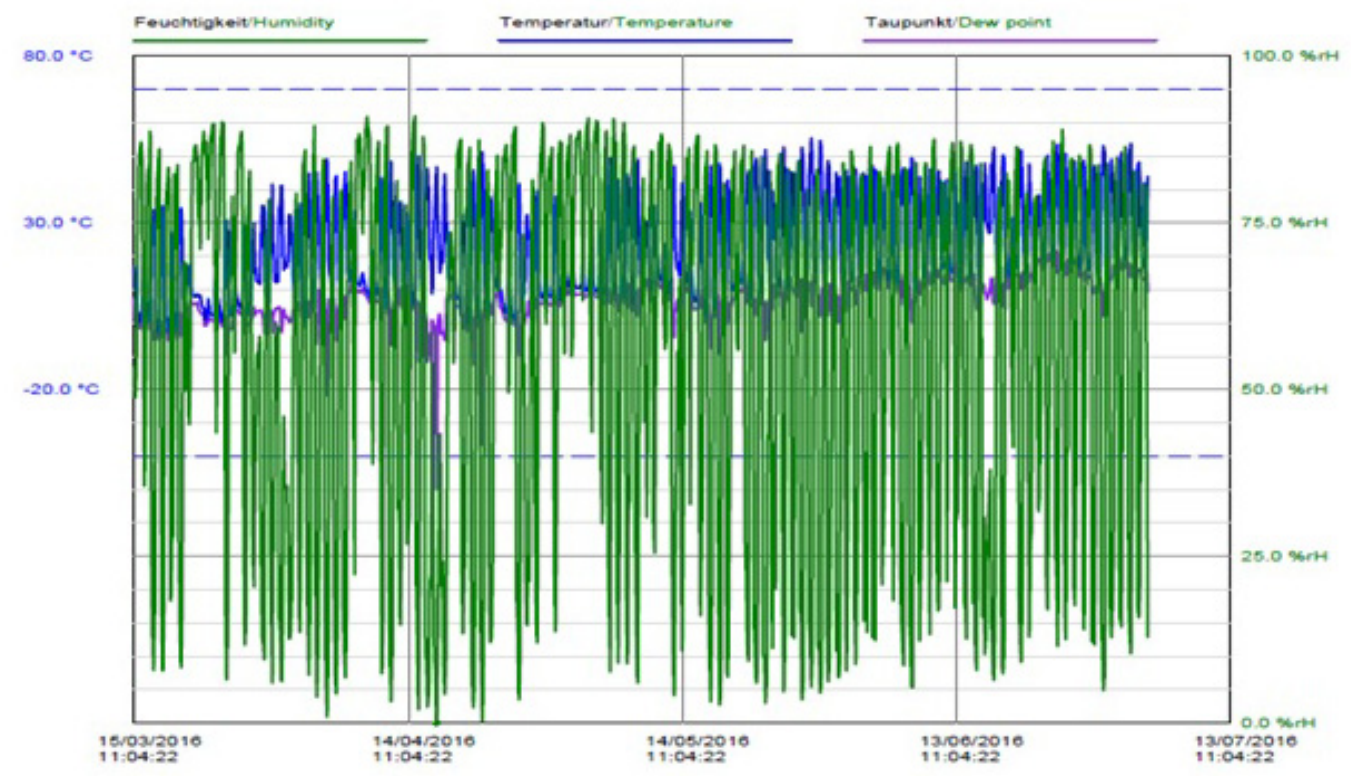

Fig. 4. Average height by year of measurement

Table 3

Statistical indicators of various Scots pine provenances

\begin{tabular}{|c|c|c|c|c|c|c|c|c|c|}
\hline \multirow[b]{2}{*}{ Provenance } & \multicolumn{3}{|c|}{ Height } & \multicolumn{3}{|c|}{ Root collar diameter } & \multicolumn{3}{|c|}{ Ratio of root collar diameter to height } \\
\hline & $\begin{array}{l}\text { average value, } \\
\mathrm{cm}\end{array}$ & $\begin{array}{c}\text { standard } \\
\text { deviation, } \mathrm{cm}\end{array}$ & $\begin{array}{l}\text { coefficient of } \\
\text { variation, } \%\end{array}$ & $\begin{array}{l}\text { average value, } \\
\mathrm{cm}\end{array}$ & $\begin{array}{c}\text { standard } \\
\text { deviation, } \mathrm{cm}\end{array}$ & $\begin{array}{l}\text { coefficient of } \\
\text { variation, \% }\end{array}$ & $\begin{array}{l}\text { average } \\
\text { value }\end{array}$ & $\begin{array}{l}\text { standard } \\
\text { deviation }\end{array}$ & $\begin{array}{l}\text { coefficient of } \\
\text { variation, } \%\end{array}$ \\
\hline Bosnia B1 & 110.97 & 26.38 & 23.78 & 3.34 & 0.90 & 26.83 & 0.0305 & 0.0070 & 23.10 \\
\hline Austria A1 & 134.28 & 30.89 & 23.01 & 4.32 & 1.11 & 25.77 & 0.0326 & 0.0069 & 21.30 \\
\hline Austria A2 & 131.16 & 26.62 & 20.30 & 3.97 & 0.94 & 23.69 & 0.0306 & 0.0056 & 18.48 \\
\hline Austria A3 & 124.75 & 32.55 & 26.09 & 3.63 & 1.14 & 31.48 & 0.0291 & 0.0051 & 17.80 \\
\hline Italy I1 & 131.31 & 24.81 & 18.89 & 3.58 & 0.89 & 24.86 & 0.0272 & 0.0041 & 15.21 \\
\hline Italy I2 & 83.45 & 24.14 & 28.93 & 2.40 & 0.69 & 28.93 & 0.0295 & 0.0059 & 20.37 \\
\hline Italy I3 & 86.23 & 26.12 & 30.30 & 2.62 & 0.73 & 27.73 & 0.0316 & 0.0068 & 21.97 \\
\hline Norway N2 & 84.98 & 19.68 & 23.16 & 2.46 & 0.65 & 26.49 & 0.0293 & 0.0055 & 18.94 \\
\hline Germany NJ2 & 106.78 & 24.33 & 22.79 & 3.29 & 0.86 & 26.20 & 0.0311 & 0.0062 & 20.01 \\
\hline Poland P1 & 138.28 & 24.65 & 17.82 & 4.09 & 0.88 & 21.45 & 0.0298 & 0.0055 & 18.46 \\
\hline Romania R1 & 24.85 & 9.43 & 37.94 & 1.03 & 0.31 & 29.65 & 0.0446 & 0.0135 & 30.88 \\
\hline Slovakia SL1 & 138.62 & 29.41 & 21.22 & 3.92 & 1.09 & 27.80 & 0.0282 & 0.0048 & 17.14 \\
\hline Scotland S1 & 136.57 & 26.47 & 19.38 & 4.00 & 0.99 & 24.79 & 0.0292 & 0.0041 & 14.24 \\
\hline Ukraine U1 & 133.89 & 23.56 & 17.60 & 3.90 & 0.79 & 20.33 & 0.0296 & 0.0076 & 25.88 \\
\hline Total & 117.85 & 37.26 & 31.61 & 3.49 & 1.18 & 33.72 & 0.0304 & 0.0070 & 23.21 \\
\hline
\end{tabular}

The coefficient of variation for the height of the different Scots pine provenances ranges from $17.6 \%$ (Ukraine U1) to $30.3 \%$ (Italy I3). The standard deviation ranges in interval of $9.43 \mathrm{~cm}$ (Romania R1) to $32.55 \mathrm{~cm}$ (Austria A3). For all the seedlings as a whole the standard deviation was $37.26 \mathrm{~cm}$. Variance analysis of height shows that there is a statistically very significant difference between the average heights of the various provenances, with a probability of $99 \%$ (Table 4 ). 
Table 4

Variance analysis of different Scots pine provenances

\begin{tabular}{lcc}
\hline \multicolumn{1}{c}{ Type of variation } & F- value & $\begin{array}{c}\text { No. Duncan's } \\
\text { test group }\end{array}$ \\
\hline $\begin{array}{l}\text { Variance analysis of the height } \\
\text { Variance analysis of root collar diameter }\end{array}$ & $\mathrm{F}_{0.01}=66.384$ & 5 \\
Variance analysis of ratio of root collar & $\mathrm{F}_{0.01}=42.759$ & 7 \\
diameter to height & $\mathrm{F}_{0.01}=15.899$ & 5 \\
\hline
\end{tabular}

The variability this yielded was confirmed using Duncan's test, where the differences between clusters are significant, while those within clusters are flukes. This test grouped the provenances into five clusters (in the case of average plant height) (Table 4).

Analysis of root collar diameter. The mean value for the root collar diameter ranges within the interval of $1.03 \mathrm{~cm}$ (Romania R1) to $4.32 \mathrm{~cm}$ (Austria A1). The other provenances, apart from Austria A1, with a mean value in excess of $4 \mathrm{~cm}$ are Poland P1 $(4.09 \mathrm{~cm})$ and Scotland $\mathrm{S} 1(4.00 \mathrm{~cm})$. Half the provenances have a mean diameter in interval of $3.00-4.00 \mathrm{~cm}$ (Table 3 ). The mean diameter for al 812 is $3.49 \mathrm{~cm}$.

The standard deviation is below $1 \mathrm{~cm}$ for 11 provenances, with only Austria A1 $(1.11 \mathrm{~cm})$, Austria A3 $(1.14 \mathrm{~cm})$ and Slovakia SL1 $(1.09 \mathrm{~cm})$ displaying a standard deviation in excess of $1 \mathrm{~cm}$. The overall standard deviation for all 812 plants is $1.18 \mathrm{~cm}$. The overall coefficient of variation is $33.7 \%$, ranging within the interval of $20.3 \%$ (Ukraine U1) to $31.4 \%$ (Austria A3). Austria A3 provenance also had a value for this coefficient in excess of $30 \%$; all other provenances had a coefficient of variation within the interval of 20 $30 \%$ (Table 3 ).

The smallest diameter was that of a plant from Romania R1 provenance, at $0.42 \mathrm{~cm}$, and the largest that of a plant from Austria A1 provenance, at $6.53 \mathrm{~cm}$. Variance analysis for root collar diameter of the various provenances yielded statistically significant differences between the characteristics studied (Table 4). The root collar diameter of Scots pine showed less variability than height, as can be seen on the basis of $\mathrm{F}_{0.01}$ value.

The results of Duncan's test show that there are statistically significant differences between provenances, which fall into 7 clusters (Table 4). These results reveal that Romania R1 provenance has no connection with the other provenances and is specific only for the first cluster (diameter $1.03 \mathrm{~cm}$ ). Cluster 2 consists of three provenances, Italy I3, Norway N2 and Italy I2 (from 2.40 to $2.62 \mathrm{~cm}$ ). There are no overlaps between the first two clusters and the other clusters. Cluster 3 consists of four provenances: Germany NJ2, Bosnia B1, Austria A3 and Italy I1 (between 3.29 and $3.63 \mathrm{~cm}$ ).

Along with two provenances that also belong to cluster 3 (Austria A3, Italy I), cluster 4 consists of Ukraine U1 and Slovakia SL1, which also occur in clusters 5 and 6. Cluster 5 also includes Austria A3, Austria A2 and Scotland S1 (between 3.63 and $4.00 \mathrm{~cm}$ ).

The last two provenances (Austria A2 and Scotland S1) also fall into clusters 6 and 7. Cluster 6 consists of the said provenances plus Poland P1, while the last cluster, cluster 7, also includes Poland P1 and Austria A1 (average diameter between 3.97 and $4.32 \mathrm{~cm}$ ).

Analysis of ratio of root collar diameter to height. The rate at which the seedlings grew in height is not proportionate to the increase in root collar diameter. As a result, the coefficient of the ratio between root collar diameter and height above ground falls as height increases. A higher value of this coefficient points to better seedling quality, and values in excess of $0.20(\mathrm{~mm} / \mathrm{cm})$ i.e. $0.02(\mathrm{~cm} / \mathrm{cm})$ indicate a good ratio between above-ground height and root collar diameter; such a seedling is of good quality (Višnjić, 2012).

The mean value of the ratio of root collar diameter to height ranges in interval from 0.0272 (Italy I1) to 0.0446 (Romania R1). The mean value of this coefficient is above 0.02 in all provenances, indicating good quality seedlings and even growth in thickness and height. The mean value of the seedlings as a whole is 0.0304 . The lowest coefficient of the ratio of diameter to height was recorded in seedlings of the Slovakia SL1 provenance, at 0.009, while the highest coefficient was recorded in seedlings of the Romania R1 provenance, at 0.0840 (Table 3). The standard deviation ranges in interval from 0.0041 (Scotland S1 and Italy I1) to 0.0135 (Romania $\mathrm{R} 1)$. The overall coefficient of variation is $23.2 \%$, ranging in interval from $14.2 \%$ (Scotland S1) to $30.9 \%$ (Romania R1).

Variance analysis of the ratio between root collar diameter and height of plants from different provenances revealed statistically significant differences between the characteristics studied (Table 4). This characteristic displays the least variability as regards diameter and height, as can be seen on the basis of $\mathrm{F}_{0.01}$ value.

The results of Duncan's test (Table 4) for this characteristic reveal great variability between provenances. The results between clusters are significant, while those within clusters are flukes. This test groups the provenances into 5 clusters. One cluster consists of one to ten provenances. The conclusion that may be drawn is that cluster 5 displays the least variability, consisting of just one provenance (Romania R1). This is followed by cluster 4, with five provenances (Bosnia B1, Austria A2, Germany NJ2, Italy I3 and Austria A1).

Provenances Austria A3, Scotland S1, Norway N2, Italy I2, Ukraine U1 and Poland P1 form clusters 1, 2 and 3. In addition, cluster 1 includes provenances Italy I1 and Slovakia SL1, cluster 2 Slovakia SL1, Bosnia B1 and Austria A2, and cluster 3, Bosnia B1, Austria A2, Germany NJ2 and Italy I3. This cluster is also the most variable, consisting of ten provenances (diameter to height ratio ranging from 0.0291 to 0.0316). Cluster 1 consists of eight provenances (coefficient between 0.0272 and 0.0298), and cluster 2, nine provenances (between 0.0282 and 0.0306 ).

Discriminant analysis. Discriminant analysis revealed that the three canonical discriminant functions encompass all $100 \%$ variables of the Scots pine characteristics we studied. However, the significance of the different discriminant functions varies. The most significant is discriminant function 1, which includes $83.1 \%$ variables. Discriminant function 2, with $13.5 \%$ variables, is more significant than function 3 . On the basis of the value of function 1 , it is clear that this function maximises the differences between groups. Its own value is 1.341 (Table 5).

Table 5

Statistical indicators of discriminant analysis

\begin{tabular}{ccccc}
\hline Function & Own value & \% variance & Cumulants, \% & Canonical correlation \\
\hline 1 & $1.341^{\mathrm{a}}$ & 83.1 & 83.1 & 0.757 \\
2 & $0.217^{\mathrm{a}}$ & 13.5 & 96.6 & 0.422 \\
3 & $0.055^{\mathrm{a}}$ & 3.4 & 100.0 & 0.229 \\
\hline Note $^{\text {a }}{ }^{\mathrm{a}}$ - in the analysis were used the first three canonical discriminant function.
\end{tabular}

Figure 5, generated by discriminant analysis, sets out the positions of the groups in multidimensional space. From this it may be concluded that two subgroups can be distinguished, the first consisting of provenances Bosnia B1, Italy I2, Italy I3, Norway N2, Germany NJ2 and Romania R1, and the second consisting of the remaining provenances: Austria A1, Austria A2, Austria A3, Italy I1, Poland P1, Slovakia SL1, Scotland S1 and Ukraine U1.

The results of the phenological observation are based on the data collected during a single year, from 30 Mar to 13 June 2016. During this period, six different phenophases were monitored.

During these observations, the beginning and end of each phenological phase was determined for each of the 14 provenances, i.e. for a total of 812 plants. The date of the earliest and latest appearance of the plants of a given provenance was recorded for all six phenophases (Table 6).

Analysis of the phenological development of Scots pine among the 14 provenances revealed that there is variability between all provenances. Differences in the beginning, duration and completion of the various phenophases were identified.

On 30 March, phase A was recorded for all provenances, all of which had dormant buds. On 6 June it was noted that the plants of all fourteen provenances had reached the final phase, i.e. that green needles were fully formed.

Based on the phenological observations, 4 April may be taken as the start of the growth season of Scots pine (the phenological phase 
where the bud begins to develop) in the international trial at Žepče, as on that date bud burst had begun in thirteen provenances. The exception is Romania provenance, where growth began on 12 April.

This phase lasted to 22 April in five provenances (Austria A1, Bosnia B1, Scotland S1, Ukraine U1 and Germany NJ2). In Romania R1, Norway N1 and Italy I2 provenances, this phase lasted until 29 April. In the remaining six provenances (Austria A2, Austria A3, Slovakia SL1, Poland P1, Italy I1 and Italy I3) this phase ended ear- liest, on 18 April. The average duration of this phenophase was 17 days; it no longer features after 29 April.

The earliest appearance of the phenophase of marked bud elongation may be taken as 4 April for provenances Austria A1, Austria A2, Bosnia B1, Scotland S1, Germany NJ2, Poland P1, Italy I1 and Italy I3, and the latest, 18 April for Romania R1, Norway N1 and Austria A3. This phenophase lasted between 21 and 39 days depending on provenance, and no longer featured after 13 May.

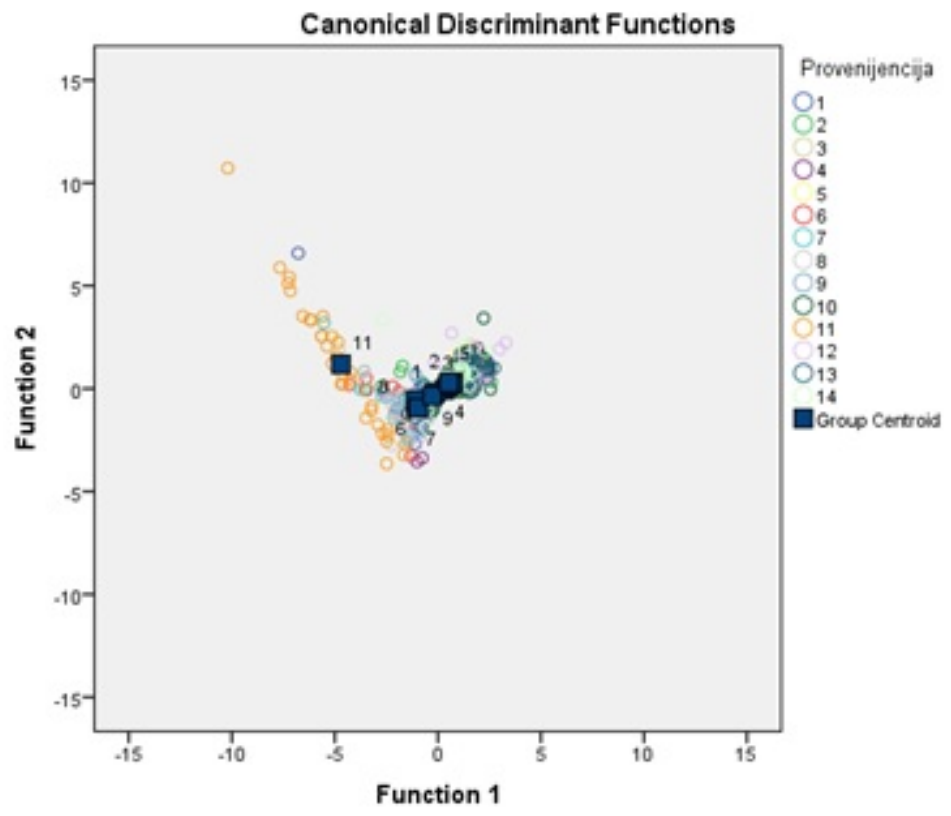

Fig. 5. Grouping of provenances based on canonical discriminant functions: 1 - Bosnia B1;2 - Austria A1; 3 - Austria A2; 4 - Austria A3; 5 - Italy I1; 6 - Italy I2; 7 - Italy I3; 8 - Norway N2; 9 - Germany NJ2; 10 - Poland P1;

11 - Romania R1; 12 - Slovakia SL1; 13 - Scotland S1; 14 - Ukraine U1

Table 6

Development of observed phenophases of different provenances of Scots pine in 2016

\begin{tabular}{|c|c|c|c|c|c|c|c|c|c|c|c|c|c|}
\hline \multirow{3}{*}{$\begin{array}{c}\text { Mark } \\
\text { of provenance } \\
\text { in plot }\end{array}$} & \multirow{3}{*}{ Provenance } & \multicolumn{12}{|c|}{ Start and end of the phenological phases } \\
\hline & & \multicolumn{2}{|c|}{$\mathrm{A}$} & \multicolumn{2}{|c|}{$\mathrm{B}$} & \multicolumn{2}{|c|}{$\mathrm{C}$} & \multicolumn{2}{|c|}{$\mathrm{D}$} & \multicolumn{2}{|c|}{$\mathrm{E}$} & \multicolumn{2}{|c|}{$\mathrm{F}$} \\
\hline & & $\mathrm{N}_{\mathrm{R}}$ & $\mathrm{N}_{\mathrm{k}}$ & $\mathrm{N}_{\mathrm{R}}$ & $\mathrm{N}_{\mathrm{k}}$ & $\mathrm{N}_{\mathrm{R}}$ & $\mathrm{N}_{\mathrm{k}}$ & $\mathrm{N}_{\mathrm{R}}$ & $\mathrm{N}_{\mathrm{k}}$ & $\mathrm{N}_{\mathrm{R}}$ & $\mathrm{N}_{\mathrm{k}}$ & $\mathrm{N}_{\mathrm{R}}$ & $\mathrm{N}_{\mathrm{k}}$ \\
\hline 1 & Austria A1 & l & 18.4 & 4.4 & 22.4 & 4.4 & 4.5 & 22.4 & 13.5 & 9.5 & 30.5 & 19.5 & l \\
\hline 2 & Austria A2 & / & 4.4 & 4.4 & 18.4 & 4.4 & 9.5 & 18.4 & 24.5 & 4.5 & 30.5 & 13.5 & / \\
\hline 3 & Austria A3 & / & 12.4 & 4.4 & 18.4 & 18.4 & 9.5 & 22.4 & 19.5 & 9.5 & 30.5 & 19.5 & / \\
\hline 4 & Bosnia B1 & / & 4.4 & 4.4 & 22.4 & 4.4 & 13.5 & 18.4 & 24.5 & 4.5 & 24.5 & 24.5 & / \\
\hline 5 & Scotland S1 & / & 12.4 & 4.4 & 22.4 & 12.4 & 9.5 & 22.4 & 24.5 & 9.5 & 30.5 & 19.5 & I \\
\hline 6 & Ukraine U1 & l & 12.4 & 4.4 & 22.4 & 12.4 & 4.5 & 18.4 & 13.5 & 4.5 & 30.5 & 19.5 & / \\
\hline 7 & Slovakia SL1 & l & 12.4 & 4.4 & 18.4 & 12.4 & 9.5 & 22.4 & 24.5 & 4.5 & 30.5 & 24.5 & l \\
\hline 8 & Romania R1 & l & 12.4 & 12.4 & 29.4 & 18.4 & 9.5 & 29.4 & 24.5 & 19.5 & 30.5 & 24.5 & / \\
\hline 9 & Norway N2 & / & 18.4 & 4.4 & 29.4 & 18.4 & 13.5 & 22.4 & 24.5 & 9.5 & 30.5 & 19.5 & I \\
\hline 10 & Germany $\mathrm{Nj} 2$ & / & 18.4 & 4.4 & 22.4 & 4.4 & 4.5 & 22.4 & 24.5 & 9.5 & 30.5 & 19.5 & / \\
\hline 11 & Poland P1 & l & 12.4 & 4.4 & 18.4 & 4.4 & 9.5 & 22.4 & 19.5 & 4.5 & 24.5 & 13.5 & I \\
\hline 12 & Italy I1 & I & 4.4 & 4.4 & 18.4 & 4.4 & 9.5 & 22.4 & 24.5 & 13.5 & 30.5 & 19.5 & I \\
\hline 13 & Italy I2 & / & 4.4 & 4.4 & 29.4 & 12.4 & 9.5 & 22.4 & 24.5 & 19.5 & 30.5 & 24.5 & I \\
\hline 14 & Italy I3 & 1 & 12.4 & 4.4 & 18.4 & 4.4 & 4.5 & 22.4 & 13.5 & 4.5 & 24.5 & 13.5 & 1 \\
\hline
\end{tabular}

Note: $\mathrm{N}_{\mathrm{R}}$ - earliest appearance phenophases; $\mathrm{N}_{\mathrm{k}}-$ latest appearance phenophases.

The earliest appearance of the phenophase of first signs of bud opening and further elongation was on 18 April (provenances Austria A2, Bosnia B1 and Ukraine U1), and the latest on 29 May, in provenance Romania R1. In the remaining nine provenances, the earliest appearance of this phenophase was 22 April. The average duration of this phenophase was 29 days; it no longer featured after 24 May.

The earliest appearance of the penultimate phenophase (needles developed, bud fully elongated) was 4 May, in provenances Austria A2, Ukraine U1, Bosnia B1, Slovakia SL1, Poland P1 and Italy I3. In provenances Romania R1 and Italy I2 this phase appeared 15 days later, on 19 May. This phenophase lasted between 11 and 26 days, and no longer featured after 30 May.

The earliest appearance of the final phenophase, in which green needles are fully developed, was on 13 May, in provenances Austria
A2, Poland P1 and Italy I3; the latest was 24 May, in provenances Bosnia B1, Slovakia SL1, Romania R1 and Italy I2. Among the remaining provenances, the earliest appearance of this phenophase was on 19 May. After 6 June the needles were fully developed on all plants, but the exact end of the growing season is hard to determine because of various microclimatic influences on the plants.

At certain intervals the simultaneous presence of as many as four phenophases was observed on the trial site, though the simultaneous presence of three phenophases was most frequently recorded. With the exception of the first and last observations, when all plants were in the first or last phenophase respectively, the largest number of plants in a given phenophase was recorded on 30 June, when 642 plants were in the final phenophase. Phases C and D were present in eight of the 13 periodical observations, while the dormant 
bud phase was observed only in the first four. The number of plants per phenological phase in the periodical observations is set out in Table 6 .

Scots pine, with its very large natural range, is known to come into leaf at different times in different areas. Observation of the phenophases of Scots pine in 2016 revealed that a given phenophase appeared on average at different intervals in all the provenances studied. This all indicates considerable individual genotype variability in the plants of the population studied, with different genotypes having different norms of reaction to more or less the same or very similar environmental conditions during a given season.

The first results of the observation of the phenological characteristics of bud burst and needle formation indicate that these observations need to be continued in order to evaluate the success and genetic variability of the provenances, and to determine the overall genetic diversity of Scots pine and the behaviour of the individual provenances at the site in question.

\section{Discussion}

This study covered 14 different Scots pine provenances, with a view to determining the differences arising from the different genetic constitutions of the provenances, which are from a range of latitudes and longitudes and from different ecological niches, with differing resistance to climatic conditions. The results of this study have confirmed this.

The measurements of the height of the plants, the root collar diameter, the ratio of diameter to height, and the phenological observations, were conducted on the 812 seedlings that survived to 2015. These characteristics were analysed using statistical methods, with a view to determining the interaction between genotype and environment. Every one of these characteristics yielded statistically significant differences between the provenances studied.

The survival rate in 2014 was $60.5 \%$. The results of the study show that the survival rate of the plants in the international trial at Žepče fell to 58\% in 2015. Descriptive analysis yielded the results of the morphological study and data on the average characteristics of the Scots pine seedlings. It was found that the average values for all 812 plants were as follows: height $(117.85 \mathrm{~cm})$, root collar diameter $(3.49 \mathrm{~cm})$ and ratio of root collar diameter to height $(0.0304)$.

The coefficient of variability was taken as the most suitable measure to examine the inter provenance variability of the Scots pine characteristics studied. The value of this coefficient for seedling height was $31.6 \%$, for root collar diameter $33.7 \%$, and for the ratio of diameter to height, $23.2 \%$.

The mean value of the ratio of root collar diameter to height ranges in interval from 0.0272 (Italy I1) to 0.0446 (Romania R1). All provenances have a mean value of this coefficient above 0.02 , indicating good plant quality and even growth of diameter and height.

According to Müller-Stracku et al. (1992), species with a disjunct range, such as the Scots pine which is the subject of this study, display great inter-provenance variability. This study did indeed display interprovenance variability. Observation of morphological parameters can yield important information on the adaptability of an individual or provenance, reflected primarily in morphological diversity, average values, variances, coefficient of variability and other statistical parameters.

Based on data on Scots pine races, Giertych (1976) is of the opinion that the best races are to be found in the eastern regions of central Europe (Latvia, Belarus, Poland). Radiating out from this central region, the quality of Scots pine diminishes in all directions. An important feature of the central European Scots pine is its great adaptability. This is particularly the case with Scots pine from Latvia and North-Eastern Poland, which displays greater increase in height than all other races in habitats ranging from Turkey to Norway and from Canada and the US to Ukraine.

The results of this study have confirmed these statements, with Scots pine from Poland having the second highest average height, at $138.28 \mathrm{~cm}$. In studies conducted in 2015 (Ban, 2015) it was found that seedlings of this provenance (Poland $\mathrm{P} 1$ ) display the greatest increase in height, and that a larger number of them are of the greatest height levels (20.00-29.99) and (30.00-39.99 cm).

At the other end of the scale from Poland P1 provenance are the conclusions that can be drawn for Romania R1 provenance. Seedlings of this provenance had the lowest height $(24.85 \mathrm{~cm})$ and diameter $(1.03 \mathrm{~cm})$ values. The 2015 studies also led to the conclusion that seedlings of this provenance have the smallest increase in size, with an average increase in height of $2.83 \mathrm{~cm}$ and of diameter of $1.8 \mathrm{~mm}$.

It is important to note that the phenological observations were conducted visually, which could lead to certain differences between observers and hence to different determinations of the various phenophases. The results of the phenological studies of Scots pine provenances displayed differences as regards the beginning, duration and end of leafing.

Though phenological observations conducted in a single year cannot lead to general conclusions on the phenological characteristics of the provenances studied and the regularity of the seasonal vegetation changes that prevail in various areas, these results may serve as a good basis for further studies, which should be continued with a view to evaluating the success and genetic variability of native and foreign provenances, and to determining the overall genetic diversity of Scots pine in Europe and the behaviour of the various provenances in different habitat conditions.

Scots pine is one of the most important commercial forest tree species of the forests of Eurasia. Uncontrolled exploitation and disorganized biological regeneration have made it vital to develop a conservation plan for this species in Bosnia and Herzegovina, which is now the southern limit of the range of Scots pine, as a result of the climate changes brought about by global warming.

In order to draw up a high quality conservation plan for the Scots pine, tests should be conducted at the biochemical level to identify existing natural stands, deal with parasites contaminating the indigenous gene pool, and introduce the results of these studies to the gene bank at the international level, with a view to comparing and monitoring the development of this species. There are artificial plantations of Scots pine in Bosnia and Herzegovina that are already posing a serious threat to indigenous populations, having been raised from seed of unknown origin (Omanović 2008).

\section{Conclusion}

A total of 812 plants were measured, with a survival rate in 2015 of $58 \%$, ranging in interval from $31 \%$ (Italy I2) to $80 \%$ (Poland P1).

With an average height of $138.62 \mathrm{~cm}$, the Scotland S1 provenance displayed the highest average value for height, while plants of Austria A1 provenance displayed the highest average root collar diameter, at $4.32 \mathrm{~cm}$.

Seedlings of Romania R1 provenance had the lowest values for both characteristics, with a height of $24.85 \mathrm{~cm}$ and average root collar diameter of $1.03 \mathrm{~cm}$. The coefficient of variation for all plants combined was $31.6 \%$ for height and $33.7 \%$ for root collar diameter.

The third characteristic to be analysed, the ratio of root collar diameter to height, had the lowest coefficient of variation (23.2\%), with the highest value in Romania R1 provenance, at 0.0446 , and the lowest in Italy I1 provenance, of 0.0272 .

Variance analysis revealed that there are statistically significant differences between the provenances studied, which was confirmed by Duncan's test.

Discriminant analysis led to the conclusion that two subgroups may be distinguished, the first consisting of the following provenances: Bosnia B1, Italy I2, Italy I3, Norway N2, Germany NJ2 and Romania R1. The second subgroup consists of the remaining provenances: Austria A1, Austria A2, Austria A3, Italy I1, Poland P1, Slovakia SL1, Scotland S1 and Ukraine U1. The phenological observations revealed that there is variability between all provenances in the beginning, duration and end of the various phenophases.

The start of the growth season of Scots pine in the international trial at Žepče may be taken as 4 April, as bud burst had begun in 
thirteen provenances on that date. The exception was Romania provenance, in which growth began on 12 April. All plants from all fourteen provenances studied had reached the final phenophase by 6 June, i.e. were displaying fully developed green needles.

The results of studies obtained in the early juvenile stage are incomplete, often marred by various shortcomings, and very often differ from those obtained in later phases, making it necessary to pursue ongoing studies of this kind.

\section{References}

Alia, R., Moro-Serrano, J., \& Notivol, E. (2001). Genetic variability of Scots pine (Pinus sylvestris) provenances in Spain: Growth traits and survival. Silva Fennica, 35, 27-38.

Ballian, D. (2000) Quality of planting material in nursery of the Federation of Bosnia and Herzegovina, seminar: Seed-seed production in $\mathrm{BiH}$ - Current Situation and Perspectives. pp. 67-70.

Ballian, D., Mujanović, E., \& Cabaravdić, A. (2009). Variability of Scots pine (Pinus sylvestris L.) in the provenance trial Glasinac - Sokolac (Bosnia and Herzegovina). Journal of the Forestry Society of Croatia, 11/12, 577-588.

Ban, N. (2015). Analysis of growth of Scots pine (Pinus sylvestris) provenances in the International Experiment near Žepče, Master work, University of Sarajevo - Faculty of Forestry, Sarajevo.

Giertych, M. (1976). Summary of results on Scots pine (Pinus sylvestris L.) height growth in IUFRO provenance experiments. Institute of Dendrology, 63-120, $157-164$.

Giertych, M., \& Oleksyn, J. (1992). Studies on genetic variation in Scots pine (Pinus sylvestris L.) coordinated by IUFRO. Silvae Genetica, 41, 133-143.

Houston Durant, T., de Rigo, D., \& Caudullo, G. (2016). Pinus sylvestris in Europe: Distribution, habitat, usage and threats. In: San-Miguel-Ayanz, J., de Rigo, D., Caudullo, G., Houston Durrant, T., \& Mauri, A. (Eds.). European atlas of forest tree species. Publication Office of the European Union, Luxemburg, e016b94, pp. 132-135.

Lojo, A., \& Balić, B. (2011). Land surface and forest land survey: The state of forests and forest land in Bosnia and Herzegovina after the Second Inventory on the Great Forest Surface 2006-2009, University of Sarajevo - Faculty of Forestry, Sarajevo, pp. 3448.

Lüdeman, G. H. (1961). Die Forstpfanzenanzuht in Kämpen und Forstbaumschulen Norddeutschlands. Diss. Georg August-Univ. Zu Göttingen in Hann. Münhen, Germany.
Mikić, T. (1991). Application of breeding methods in raising intensive forest tree cultivations in order to increase the production of wood mass with a short rotation period, Report for the period 1989-1990 under D.C. VII, Sarajevo.

Mirov, N. T. (1967). The genus Pinus. Ronald Press Co., New York.

Müller-Starck, G., Baradat, P. H., \& Bergmann, F. (1992). Genetic variation within European tree species. New Forests, 6, 23-47.

Nilsson, J. E., \& Walfridsson, E. A. (1995). Phenological variation among plustree clones of Pinus sylvestris L. in Northern Sweden. Silvae Genetica, 44, 20-28.

Oleksyn, J. (1988). Report on the IUFRO - 1982 provenence experiment on Scots pine (P. sylvestris L.). Arboretum Kóornickie, 33, 211-229.

Omanović, M. (2008). Biochemical characterization of natural populations of Scots pine (Pinus sylvestris L.) in the part of the distribution in Bosnia and Herzegovina, Master work, University of Sarajevo Faculty of Sciences, Sarajevo.

Perks, M. P., \& Ennos, R. A. (1999). Analysis of genetic variation for quantitative characters between and within four native populations of Scots pine (Pinus sylvestris). Botanical Journal of Scotland, 51, 103-110.

Persson, B., \& Beuker, E. (1997). Distinguishing between the effects of changes in temperature and light climate using provenance trials with Pinus sylvestris in Sweden. Canadian Journal of Forest Research, 27, 572-579.

Persson, T., \& Andersson, B. (2003). Genetic variance and covariance patterns of growth and survival in northern Pinus sylvestris. Scandinavian Journal of Forest Research, 18, 332-343.

Prus-Glowacki, W., \& Stephan, B. R. (1994). Genetic variation of Pinus sylvestris from Spain in relation to other European populations. Silvae Genetica, 43, 7-14.

Prus-Glowacki, W., Urbaniak, L., \& Zubrowska-Gil, M. (1993). Allozyme differentiation in some European populations of Scots pine (Pinus sylvestris L.). Genetica Polonica, 34, 159-176.

Puglisisi, S., \& Attolico, M. (2000). Allozyme variation in natural populations of the Italian range of Pinus sylvestris L. Forest Genetics, 7, 221-232.

Stefanović, V., Milanović, S., Međedović, S., Pintarić, K., Rončević, S., \& Sisojević, D. (1980). Scots pine (Pinus sylvestris L.) ecotypes in Bosnia, Special editions No. 13, Faculty of Forestry and the Forestry Institute of Sarajevo, Sarajevo, pp. 9-25.

Vidaković, M., \& Franjić, J. (2004). Gymnosperms, Faculty of Forestry University of Zagreb, Zagreb, 411-417, 602-628.

Višnjić, Ć. (2012). Drafting of standards and standards on the quality of forests planting material in $\mathrm{FBiH}$ and their alignment with EU (2008) regulations and standards. Report for the FMPVS. 